\title{
Erratum: Xavier et al. High Maternal Omega-3 Supplementation Dysregulates Body Weight and Leptin in Newborn Male and Female Rats: Implications for Hypothalamic Developmental Programming. Nutrients 2021, 13, 89
}

Soniya Xavier ${ }^{1}$, Jasmine Gili ${ }^{1}$, Peter McGowan ${ }^{2}$, Simin Younesi ${ }^{1}$, Paul F. A. Wright ${ }^{1}$, David W. Walker ${ }^{1}$ (D), Sarah J. Spencer $1,3, *,+$ and Luba Sominsky $1,+\mathbb{D}$

1 School of Health and Biomedical Sciences, RMIT University, Melbourne, VIC 3083, Australia; soniya.xavier@student.rmit.edu.au (S.X.); jasminegili97@hotmail.com (J.G.); Simin.Younesi@student.rmit.edu.au (S.Y.); paul.wright@rmit.edu.au (P.F.A.W.); David.Walker@rmit.edu.au (D.W.W.); Luba.Sominsky@rmit.edu.au (L.S.)

2 School of Science, RMIT University, Melbourne, VIC 3001, Australia; peter.mcgowan@rmit.edu.au

3 ARC Centre of Excellence for Nanoscale Biophotonics, RMIT University, Melbourne, VIC 3001, Australia

* Correspondence: Sarah.Spencer@rmit.edu.au; Tel.: +61-3-9925-7745

+ These authors contributed equally to this work.

\section{check for}

updates

Citation: Xavier, S.; Gili, J.; McGowan, P.; Younesi, S.; Wright, P.F.A.; Walker, D.W.; Spencer, S.J.; Sominsky, L. Erratum: Xavier et al. High Maternal Omega-3

Supplementation Dysregulates Body Weight and Leptin in Newborn Male and Female Rats: Implications for Hypothalamic Developmental Programming. Nutrients 2021, 13, 89. Nutrients 2021, 13, 2418. https:// doi.org/10.3390/nu13072418

Received: 12 May 2021

Accepted: 12 July 2021

Published: 15 July 2021

Publisher's Note: MDPI stays neutral with regard to jurisdictional claims in published maps and institutional affiliations.

Copyright: (C) 2021 by the authors. Licensee MDPI, Basel, Switzerland. This article is an open access article distributed under the terms and conditions of the Creative Commons Attribution (CC BY) license (https:// creativecommons.org/licenses/by/ $4.0 /)$.
The authors would like to correct a typographical error in their recently published paper [1]. In the original article, there was a mistake in Table 1 as published. In Table 1 , the correct Total Calculated Energy From Protein for $\omega 3$ diet is 22\% (instead of $10 \%$ ) and Total Calculated Energy From Lipids for $\omega 3$ diet is $10 \%$ (instead of 22\%). The corrected Table 1 appears below. The authors apologize for any inconvenience caused and state that the scientific conclusions are unaffected. The original article has been updated.

Table 1. Nutritional parameters and fatty acids composition of chow, HFSD and $\omega 3$ diets.

\begin{tabular}{llll}
\hline \multirow{2}{*}{ Calculated Nutritional Parameters } & \multicolumn{2}{c}{ Diet } \\
\cline { 2 - 4 } & Chow & HFSD & w3 \\
\hline Protein $(\%)$ & 20.0 & 19.4 & 19.4 \\
Total Fat $(\%)$ & 4.8 & 20.0 & 5.0 \\
Total Carbohydrate (\%) & 59.40 & No data & 63.3 \\
Sucrose (\%) & 0.0 & 39.60 & 10.0 \\
Digestible Energy (MJ/kg) & 14.0 & 18.4 & 15.8 \\
Total Calculated Energy From Protein (\%) & 23.0 & 19.0 & 22.0 \\
Total Calculated Energy From Lipids (\%) & 12.0 & 36.0 & 10.0 \\
\hline Calculated Fatty Acid Composition (\%) & & & \\
\hline Linoleic Acid 18:2 $\omega 6$ & 1.30 & 2.90 & 0.06 \\
$\alpha$-Linolenic Acid 18:3 $\omega 3$ & 0.30 & 0.30 & 0.02 \\
Arachidonic Acid 20:4 $\omega 6$ & 0.01 & No data & 0.08 \\
EPA 20:5 $\omega 3$ & 0.02 & No data & 0.27 \\
DHA 22:6 $\omega 3$ & 0.05 & No data & 1.19 \\
Total $\omega 3$ & 0.37 & 0.31 & 1.66 \\
Total $\omega 6$ & 1.31 & 2.90 & 0.23 \\
Total Monounsaturated Fats & 2.00 & 7.32 & 1.10 \\
Total Polyunsaturated Fats & 1.77 & 3.32 & 1.91 \\
Total Saturated Fats & 0.74 & 9.30 & 1.67 \\
\hline
\end{tabular}

HFSD: high-fat-high-sugar diet. Data are from Specialty Feeds, Glen Forrest, WA, Australia. 
Author Contributions: Conceptualization, S.J.S. and L.S.; Investigation, S.X., J.G., P.M., S.Y., S.J.S. and L.S.; Methodology, S.X., P.M., P.F.A.W., D.W.W., S.J.S. and L.S.; Formal analysis, S.X., P.M., S.J.S. and L.S.; Writing—original draft preparation, S.J.S. and L.S.; Writing—review and editing, S.X., J.G., P.M., S.Y., P.F.A.W. and D.W.W.; Supervision, S.J.S. and L.S.; Project administration, S.X., S.J.S. and L.S.; Resources, S.J.S. and L.S. All authors have read and agreed to the published version of the manuscript.

Funding: This project was supported by funding from a National Health and Medical Research Council Career Development Fellowship II (APP1128646) to S.J.S., an RMIT Vice-Chancellor's Postdoctoral Fellowship and RMIT Vice-Chancellor's Research Excellence Award to L.S. and an RMIT PhD Scholarship to S.X. and S.Y.

Conflicts of Interest: The authors declare no conflict of interest.

\section{Reference}

1. Xavier, S.; Gili, J.; McGowan, P.; Younesi, S.; Wright, P.F.A.; Walker, D.W.; Spencer, S.J.; Sominsky, L. High maternal omega3 supplementation dysregulates body weight and leptin in newborn male and female rats: Implications for hypothalamic developmental programming. Nutrients 2021, 13, 89. [CrossRef] [PubMed] 